\title{
Mice lacking cyclin D1 are small and show defects in eye and mammary gland development
}

\author{
Vera Fantl, ${ }^{1}$ Gordon Stamp, ${ }^{2}$ Anton Andrews, ${ }^{1}$ Ian Rosewell, ${ }^{3}$ and Clive Dickson ${ }^{1,4}$ \\ ${ }^{1}$ Laboratory of Viral Carcinogenesis and ${ }^{3}$ Transgenic Animal Unit, Imperial Cancer Research Fund (ICRF), London, UK; \\ ${ }^{2}$ Royal Postgraduate Medical School, Hammersmith Hospital, London, UK
}

\begin{abstract}
Using homologous recombination, mice lacking cyclin D1 were generated by replacing most of the first exon of the Cyl-1 gene with sequences encoding neomycin resistance. $\mathrm{Cyl-1^{-1 }}$ mice were viable and fertile but consistently smaller than their heterozygous or wild-type littermates. The nullizygous animals also showed two distinctive abnormalities: a severe retinopathy caused by impaired development of all layers of the retina and, in the mammary gland during pregnancy, a marked reduction in acinar development accompanied by a failure to lactate. Approximately $50 \%$ of animals also had a malformation of the jaw that manifested itself as a misalignment of the incisor teeth. Mouse embryo fibroblasts isolated from 14 day nullizygous, heterozygous, or wild-type embryos and grown under standard conditions showed similar cell-cycle and growth characteristics. Thus although cyclin D1 kinase activity may facilitate $G_{1}$ progression, it is not essential for the development of most tissues and organs, and only a few specialized cell lineages are demonstrably sensitive to its absence.
\end{abstract}

[Key Words: Cyl-1; cyclin D1; gene targeting; null mutation; developmental abnormalities]

Received August 10, 1995; revised version accepted August 23, 1995.

The mammalian cell division cycle is regulated by the sequential activation of a series of cyclin-dependent protein kinases (cdks) whose function relies on association with a specific regulatory subunit, or cyclin /for review, see Norbury and Nurse 1992; Reed 1992; Pines 1993a; Hunter and Pines 1994). Although the activity of each holoenzyme is modulated further by specific phosphorylation or dephosphorylation, the temporal order of events is primarily dependent on the synthesis of the cyclin. Thus, cyclins D1, D2, and D3 in conjunction with their catalytic partners cdk 4 and cdk6 appear to regulate the initial phases of the cell cycle, as cells exit $\mathrm{G}_{0}$ or progress through $\mathrm{G}_{1}$ (Matsushime et al. 1992, 1994; Xiong et al. 1992; Bates et al. 1994; Meyerson and Harlow 1994). The subsequent transitions are executed by complexes between cyclin $\mathrm{E}$ and cdk2, cyclin $\mathrm{A}$ and cdk2, and cyclin B and cdk1 (cdc2) (for review, see Pines 1993b; Sherr 1993).

The multiplicity of D-type cyclin/kinase complexes and their early appearance in cells exposed to growth factors, make them good candidates for coupling signal transduction pathways with the cell cycle machinery. The levels of these complexes reach a maximum in late $\mathrm{G}_{1}$ phase, at a time roughly coincident with the restriction point (Pardee 1989; Matsushime et al. 1991). This is an operationally defined transition, at which cells become irrevocably committed to the division cycle irre-

${ }^{4}$ Corresponding author. spective of external stimuli and correlates temporally with the hyperhosphorylation and functional inactivation of the retinoblastoma gene product $(\mathrm{pRb}$ ) (Pardee 1989; for review see Hollingsworth et al. 1993; Weinberg 1995). Whether these two checkpoints are equivalent remains unproven, but it is clear that $\mathrm{pRb}$ and the related p107 protein are major substrates for the cyclin D-dependent kinases (Beijersbergen et al. 1995; for review, see Weinberg 1995).

The evidence favoring a functional link between $\mathrm{D}$-type cyclins and $\mathrm{pRb}$ is persuasive. Microinjection of a monoclonal antibody that neutralizes cyclin Dl function causes normal cells to arrest in $G_{1}$, but this arrest is not seen in cells that lack functional $\mathrm{pRb}$ (Baldin et al. 1993; Quelle et al. 1993; Lukas et al. 1994). Similarly, in cells synchronously released from $\mathrm{G}_{0}$ by addition of growth factors, the antibody will only have an effect if injected prior to a time in $G_{1}$ corresponding roughly to the $\mathrm{pRb}$ checkpoint. A specific inhibitor of D-cyclin/kinase function, such as the product of the tumor suppressor gene p16, also causes a late $G_{1}$ arrest that is dependent on the presence of functional pRb (for review, see Sherr and Roberts 1995).

Although all six complexes involving the D-type cyclins and either cdk4 or cdk6 appear capable of phosphorylating $\mathrm{pRb}$ in vitro, it is unlikely that in vivo they are functionally equivalent (Matsushime et al. 1992; Dowdy et al. 1993; Ewen et al. 1993; Kato et al. 1993; Meyerson and Harlow 1994). For example, it is well established 
that deregulated expression of cyclin D1 occurs in a number of human cancers, yet there is little direct evidence to implicate cyclins D2 and D3 similarly (for review, see Peters 1994). In some tumors, such as mantle cell lymphomas carrying the $t(11 ; 14)$ translocation, cyclin D1 is activated in cell types that do not normally express the gene. In breast and squamous cell carcinomas, on the other hand, amplification of cyclin D1 simply increases the level of a gene that is already expressed. Attempts to confirm the oncogenicity of cyclin D1, by overexpressing the cDNA in transfected cells or in transgenic mice, have given confusing results (Ando et al. 1993; Jiang et al. 1993; Quelle et al. 1993; Bodrug et al. 1994; Lovec et al. 1994; Resnitzky et al. 1994; Wang et al. 1994). In some systems, ectopic expression of cyclin Dl can accelerate the $G_{1}$ phase, as predicted for a positive regulator of cdks, but in others, excessive cyclin D1 inhibits proliferation (Ando et al. 1993; Jiang et al. 1993; Quelle et al. 1993; Resnitzky et al. 1994). In the mammary gland, ectopic expression of cyclin D1 leads to abnormal proliferation, whereas in B cells its oncogenic effect is only apparent when coexpressed with c-myc (Bodrug et al. 1994; Wang et al. 1994). To try to gain further insights into the tissue specificity, functional redundancy and oncogenicity of the D-type cyclins, we have used homologous recombination in embryonic stem (ES) cells to generate mice lacking cyclin Dl protein.
Results

\section{Targeted disruption of Cyl-1 in ES cells}

The five coding exons of the mouse $\mathrm{Cyl}-1$ gene extend over $\sim 12 \mathrm{~kb}$ of genomic DNA (Fig. 1A; Smith et al. 1995). The first exon of 336 bp encodes the LXCXE motif (Dowdy et al. 1993; Ewen et al. 1993), which is characteristic of proteins that interact with $\mathrm{pRb}$, as well as several amino acids of the cyclin box motif. The targeting vector effectively replaced $200 \mathrm{bp}$ of exon 1 , between codon 2 and a NheI site in the first intron, with $1.8 \mathrm{~kb}$ of a PGK-neo cassette (see Fig. 1A; Materials and methods). Electroporation of the vector into ES cells, using established procedures (see Materials and methods), gave rise to G418-resistant colonies that were screened by Southern blotting with probe 1 from exon 5 of $C y l-1$ (Fig. 1A). Of 400 G418-resistant colonies tested, four clones gave an additional band of the size predicted for a mutant allele arising from homologous recombination. Further analysis of two of these clones (D40 and E8) confirmed their status and they were used to generate mutant mice.

Generation of mice with heterozygous and homozygous disruption of the Cyl-1 gene

Chimeric mice were generated by injection of D40 or E8 recombinant ES cell clones into C57BL/6J blastocysts.
A
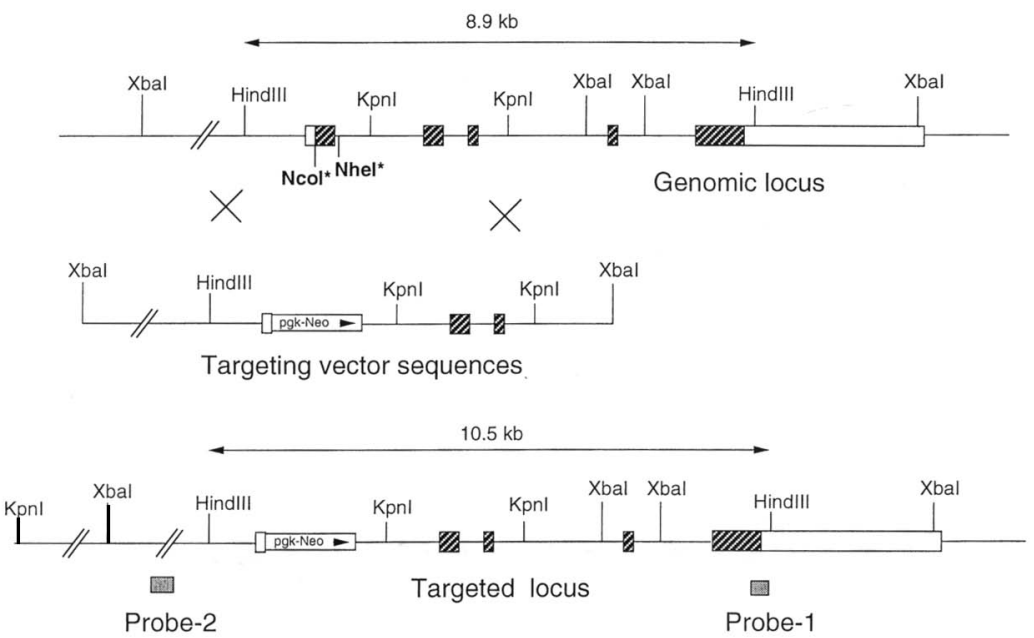

B

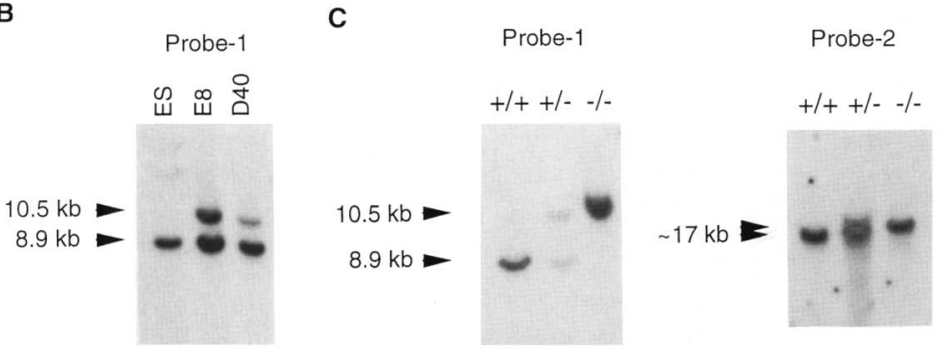

Figure 1. Organization of the Cyl-1 gene and detection of recombinant alleles. (A) Approximately $12 \mathrm{~kb}$ of the mouse Cyl-1 locus is depicted with exons as boxes and the coding domains shaded (top). Restriction endonuclease sites marked with an asterisk are not unique. The targeting vector (center) was constructed from an $\mathrm{Xbal}$ fragment $(\sim 10 \mathrm{~kb})$ by replacing part of the first exon between restriction sites $\mathrm{Ncol}$ and NheI /marked in boldface letters|, with a PGK-neo cassette in the same transcriptional orientation as Cyl-1. The predicted structure of the disrupted allele (bottom) shows the $3^{\prime}$ and $5^{\prime}$ probes used to distinguish it from the wild-type allele. Hybridization of HindIII-digested DNA with the $3^{\prime}$ probe yielded fragments of 8.9 and $10.5 \mathrm{~kb}$ for the wildtype and targeted loci, respectively. KpnI-digested DNA, hybridized with the $5^{\prime}$ probe, produced a fragment that was $1.6 \mathrm{~kb}$ larger for the mutant allele than the $\sim 17-\mathrm{kb}$ normal allele. $\langle B|$ Southern blot analysis of HindIII-digested DNA from untransfected cells (ES) and from the two recombinant clones used to generate chimeric mice (E8, D40). Hybridization with probe 1 showed that E8 and D40 were heterozygous for the disrupted Cyl-1 allele. $(C)$ Genotype of embryos obtained by mating heterozygote mice derived from clone E8. DNAs from three embryos initially identified as $+1+,+1-$, and $-1-$ for Cyl-1 by PCR /see Materials and methods) were digested with HindIII or KpnI and hybridized with probes 1 and 2, respectively. 
Fantl et al.

Transmission of the mutant gene was determined by $P C R$, and $F_{1}$ mice carrying the disrupted allele were interbred. Two independent colonies of mice generated from clones D40 and E8, respectively, were maintained, and both gave rise to similar phenotypes. The genotype of $F_{2}$ progeny carrying no, one, or two copies of the mutant or wild-type allele was established by PCR. Southern analysis of DNA from Cyl-1+1+, $\mathrm{Cyl-1} 1^{+1-}$ and Cyl-1 $1^{-1}$ embryos confirmed the reliability of genotyping by PCR (Fig. 1C). Heterozygous crosses yielded a slightly lower proportion of $\mathrm{Cyl}-1^{-1-}$ mice than expected for the segregation of a single affected allele, suggesting that there was a significant degree of embryonic lethality for the $\mathrm{Cyl-1^{-/ }}$ genotype (Table 1). It was also apparent that virtually all mice null for Cyl-1 were abnormally small when compared with their heterozygous and wild-type littermates (Fig. 2A). During subsequent growth to adulthood, the $C y \mathrm{l}_{-1}^{-1-}$ animals remained proportionately smaller (between $10 \%$ and $40 \%$ ), as illustrated by the growth curves of representative litters (Fig. 2B,C).

To determine whether there was any detectable expression of Cyl-1 transcripts in mice with both Cyl-1 alleles disrupted, total RNA for Northern blot analysis was isolated from several different tissues of $\mathrm{Cyl}-1^{-1-}$ mice and a wild-type littermate. Tissues were selected on the basis that they normally express readily detectable levels of $C y 1-1$ transcripts (V. Fantl, unpubl.). A probe from exon 5 that hybridizes to the 3 ' portion of the mRNA, downstream of the PGK-neo cassette, was used. A prominent transcript of $4.0 \mathrm{~kb}$ was observed in tissues from the $C y l^{-1+}$ mouse, but no specific signal was discernible in RNA samples from $\mathrm{Cyl} 1^{-1-}$ mice (Fig. $3 \mathrm{~A}$ ). To determine whether there were any changes in expression of other D-type cyclins, the same blot was rehybridized sequentially with probes to Cyl-2, Cyl-3, and finally to $\beta$-actin to act as an RNA loading control (Fig. 3A). In some tissues from $\mathrm{Cyl}^{-1} 1^{-1-}$ mice there appeared to be slightly elevated levels of Cyl-2 RNA compared to the $\beta$-actin controls, but $C y l-3$ RNA levels were comparable.

Although there were no detectable Cyl-1 transcripts in mice with the disrupted allele, we sought to confirm these observations at the protein level. Extracts were prepared from wild-type and $\mathrm{Cyl-1^{-1- }}$ tissues and immunoblotted using a rabbit antiserum against the carboxy-terminal peptide of cyclin D1. The $36-\mathrm{kD}$ cyclin

Table 1. Transmission of the mutant Cyl-1 gene from Cyl-1 ${ }^{+1-}$ pairings

\begin{tabular}{lccrl}
\hline Mouse line & Total & Cyl-1 & Cyl-1 & Cyl-1-1- \\
\hline D40 & 118 & $37(31 \%)$ & $58(49 \%)$ & $23(19 \%)$ \\
E8 & 158 & $45(28 \%)$ & $86(54 \%)$ & $27(17 \%)$ \\
Overall & 276 & $82(30 \%)$ & $144(52 \%)$ & $50(18 \%)$ \\
\hline
\end{tabular}

The percentage of $\mathrm{Cyl}-1^{-1-}$ progeny was lower than would be expected $(25 \%)$ for the segregation of a single mutant allele $(P=$ $0.007)$.
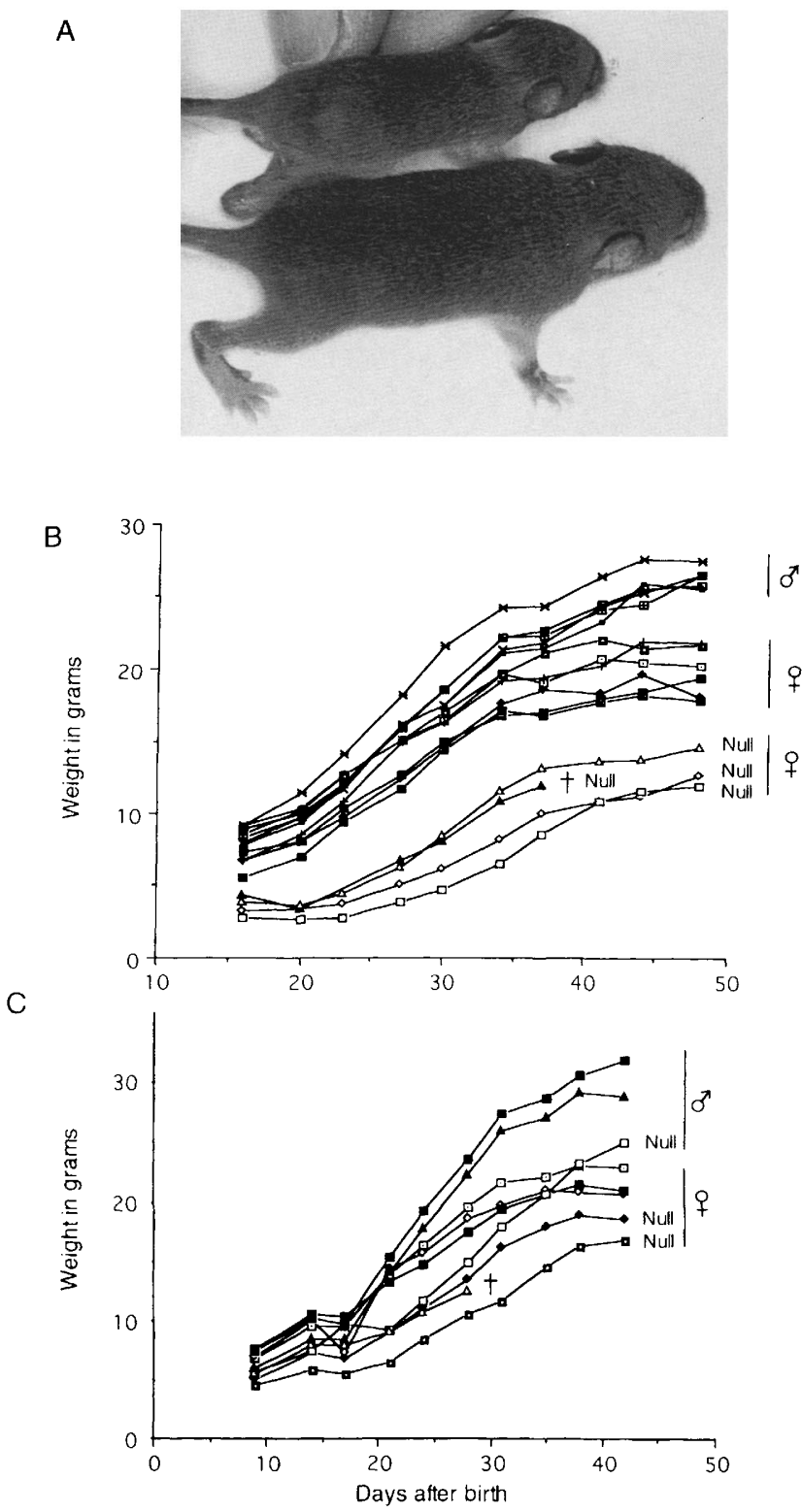

Figure 2. Growth of mice derived from $\mathrm{Cyl}-1^{+1-}$ intercrossing. (A) Typical example showing the size difference between Cyl-1 $1^{-1-}$ and $C y l-1^{+1}-$ littermates at 10 days. $(B, C)$ Two litters originating from mice derived from recombinant ES clones D40 and $\mathrm{E} 8$, respectively, were weighed at intervals and plotted against age in days. Cyl-1-1- littermates are indicated as null. A plus sign $(+)$ indicates death.

Dl protein, which migrates as a doublet, was only detected in extracts from the wild-type animals (Fig. 3B; Matsushime et al. 1991; Bates et al. 1994).

\section{Anatomical and histopathological abnormalities associated with Cyl-1-1- mice}

Several $\mathrm{Cyl}-1^{-1-}, \mathrm{Cyl}-1^{-1+}$, and wild-type littermates were autopsied to investigate the presence of developmental abnormalities. In general, the weights and sizes 
A

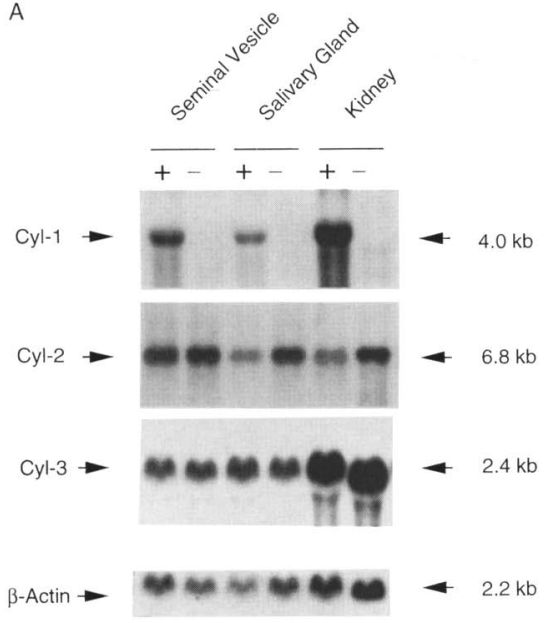

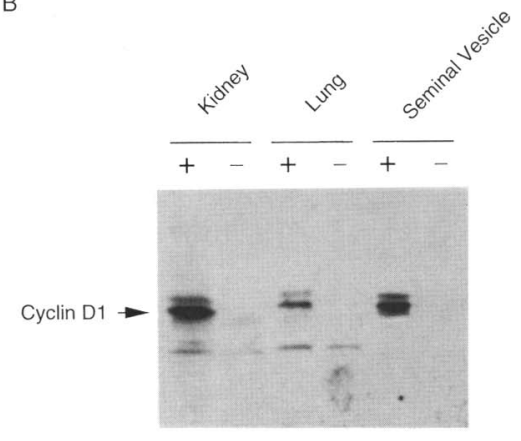

Figure 3. D-type cyclin expression in Cyl$1^{-1-}$ mice. $(A)$ Northern blot analysis using total RNA prepared from selected tissues as indicated of wild-type and homozygous mutant mice. Hybridization with ${ }^{32} \mathrm{P}$ labeled cDNA for each of the D-type cyclins detected transcripts of expected size in all tissues for Cyl-2 and Cyl-3, but Cyl-1 was only detected in tissues from wild-type littermates. A probe to $\beta$-actin was used as a control for sample loading. $|B|$ Western blot analysis of cell extracts from tissues as indicated were prepared from a wild-type and a $\mathrm{Cyl}-1^{-1-}$ mouse. Immunoblotting with a rabbit antiserum to cyclin D1 (see Materials and methods) showed detectable protein only in tissue from the normal littermate. of the major organs of $C y 1-1^{-1-}$ mice were proportionately lower in keeping with their smaller size. Moreover, the histological appearance of these tissues was not discernibly different from the Cyl-1-1+ and wild-type animals, except for the abnormalities described below.

Direct observation showed $\sim 50 \%$ of the $\mathrm{Cyl}-1^{-1-}$ mice had a misalignment of the incisor teeth, leading to their excessive growth (Fig. 4). In a few severe cases, the teeth needed to be reduced in length to allow the mice to feed properly. However, it should be noted that the small size of the Cyl-1-1- mice was not attributable to the misalignment affecting feeding, as mice without such defects were equally runted. To investigate the underlying cause of the misaligned incisors, selected mice were examined radiologically. Results indicated that while development of the teeth was normal, lateral distortion of the mandibles in the anterior part of the jaw was causing misalignment of the incisors. In one case, there was a marked distortion of the maxilla on one side (Fig. 4).

As part of a detailed histological analysis, several eyes from nullizygous and wild-type mice were examined. The stained sections revealed a striking reduction in thickness and organization of the retinal layers (Fig. 5). Comparison of cell numbers in the two nuclear layers confirmed that a reduction in thickness was most marked for the outer layer (Table 2) and accompanied by disorganization of nuclear polarity. A reduction in thickness and organization of the surface ganglion cell layer was also seen. The remainder of the eye structure appeared normal. These features are consistent with a severe retinopathy, and in all cases examined it was bilateral. The maximal diameters of eyes from $C y 1_{-1}^{-1-}$ mice $(2.03 \pm 0.14 \mathrm{~mm})$ were not significantly different from control mice $(2.33 \pm 0.31 \mathrm{~mm})$, taking into account the difference in size between the two groups.

Despite their reduced size, both male and female $\mathrm{Cyl}$ $1^{-1-}$ mice proved to be fertile, and litters of up to 11 young were produced from such pairings. However, litters were invariably killed by their mothers, never surviving beyond the second day. Such litters could only be rescued when cross-fostered. This prompted us to exam- ine the mid-pregnant and postpartum mammary glands to determine whether there was a problem with their growth or differentiation. At both stages of development, mammary glands of $C y l-1^{-1}$ mice showed poor acinar development and very little secretory activity (Fig. 6).

\section{Cell cycle kinetics for embryo fibroblast lines from Cyl-1 ${ }^{-1-}$ mice}

To investigate the growth of cells with and without cyclin D1, mouse embryo fibroblast (MEF) cultures were
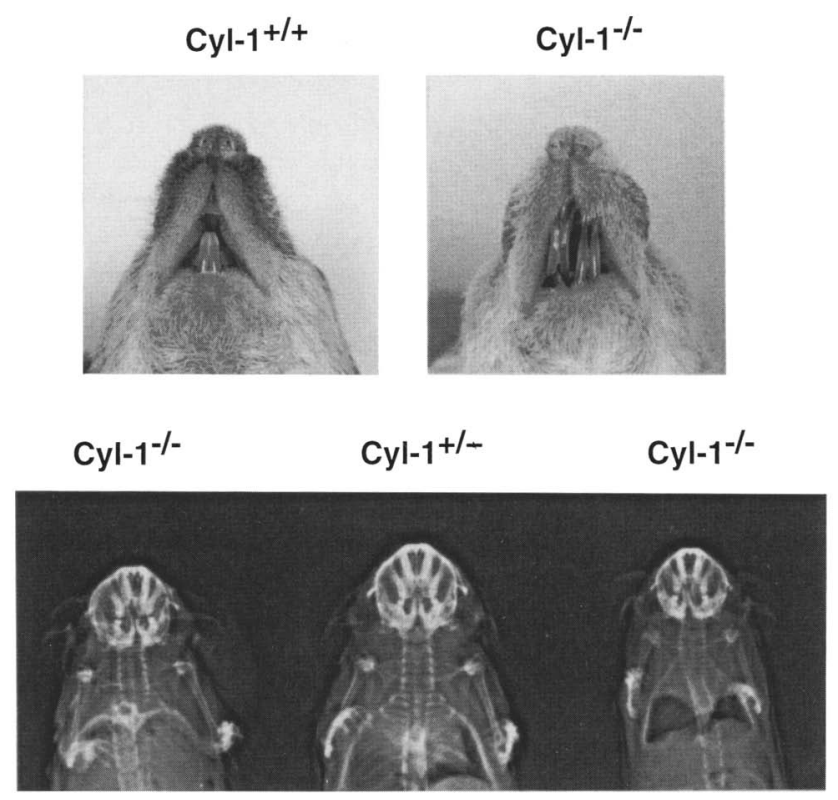

Figure 4. Skeletal abnormalities in $\mathrm{Cyl-1^{-1- }}$ mice. Approximately $50 \%$ of $\mathrm{Cyl}-1^{-1-}$ mice showed a malformation of the jaw, giving rise to unchecked growth of the incisor teeth (top right) because of their misalignment. This was not observed in any wild-type (top left) or heterozygous (not shown) littermates. Radiological analysis of such mice (bottom left and right) showed lateral distortion of the mandibles. (Bottom center) An unaffected heterozygous littermate of the mouse on the left. 
Figure 5. Histological analysis of the eye from $\mathrm{Cyl}-1^{-1-}$ mice. Section through the retina of a Cyl-1-1- mouse (right) and a wild-type littermate (left) showing the layered structure. A marked reduction in overall thickness, which affected all layers, and loss of organization of some of the retinal layers is apparent (right). The layers indicated are as follows: (G) Surface ganglion cell layer; (ON) outer nuclear layer; (IN) inner nuclear layer; (OP) outer plexiform layer; (IP) inner plexiform layer; (P) photoreceptor cell layer; (C \& P) choroid and pigment cells.

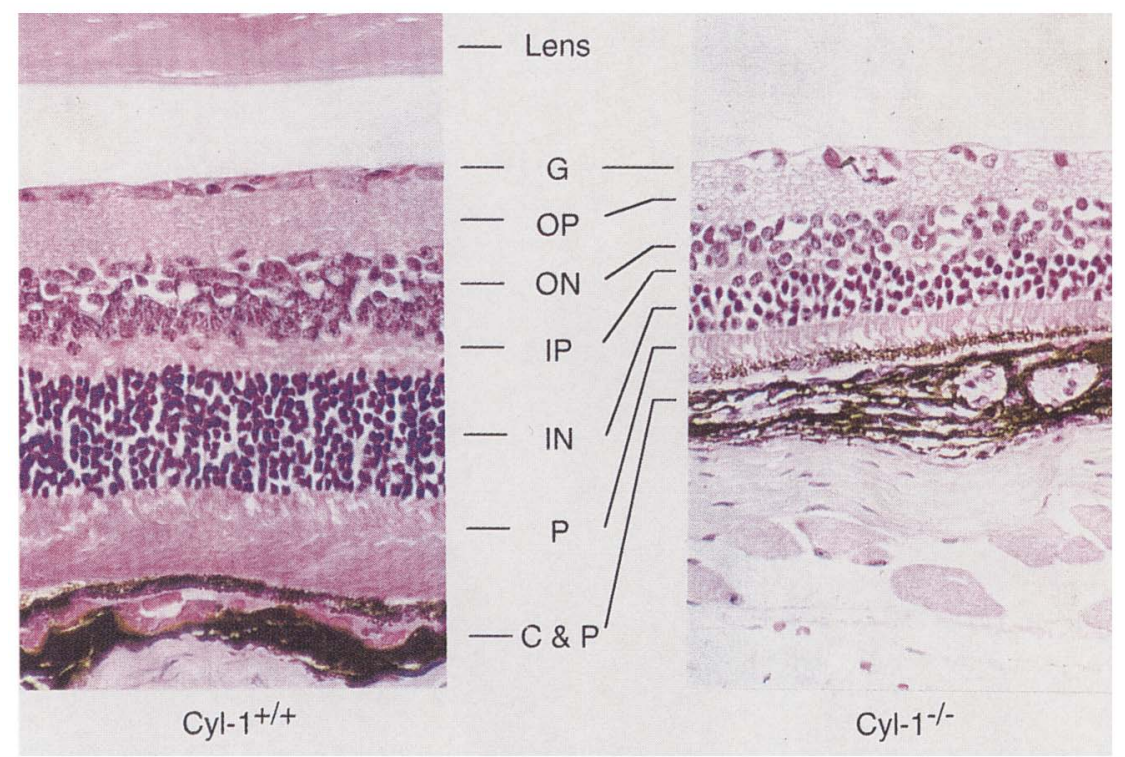

prepared from a number of individual 14 day embryos derived from heterozygous crosses. The different embryo cell cultures were genotyped by PCR and their growth rates compared as described in Materials and methods. Most of the cell cultures showed similar growth rates, whether they were from $\mathrm{Cyl}-1^{-1-}, \mathrm{Cyl}-1^{-1+}$, or Cyl$1^{+1+}$ mice, although two lines, one wild-type (not shown) and one mutant, have shown a slower rate of growth (Fig. 7). Following serum stimulation of quiescent MEFs, the proportion of cells in different phases of the division cycle $\left(G_{0} / G_{1}, S\right.$, and $\left.G_{2} / M\right)$ was monitored at intervals by flow cytometry. The results show that embryo cell cultures derived from $\mathrm{Cyl-1^{-1 }}$ and $\mathrm{Cyl}$ $1^{+1+}$ mice displayed indistinguishable kinetics for entry into, and progression through, the cell division cycle (Fig. 8). Cells started to enter $\mathrm{S}$ phase between 15 and 18 $\mathrm{hr}$, with a maximum proportion in $\mathrm{S}$ phase at $21 \mathrm{hr}$. At this time, there was a noticeable increase of cells entering $\mathrm{G}_{2} / \mathrm{M}$, which peaks at $28 \mathrm{hr}$.

Total cell extracts were prepared from the synchronized $\mathrm{Cyl}-1^{-1-}$ and $\mathrm{Cyl}-1^{+1+}$ MEFs above at the time points indicated, and cyclin protein levels were measured by immunoblotting (Fig. 9). As expected, there was

Table 2. Comparison of retinal tissue from Cyl-1 ${ }^{+1+}$, Cyl-1 ${ }^{+1-}$, and Cyl-1 ${ }^{-1-}$ mice

\begin{tabular}{lccr}
\hline & & \multicolumn{2}{c}{$\begin{array}{c}\text { Nuclear cell layer } \\
\text { (no. of nuclei) }\end{array}$} \\
\cline { 3 - 4 } Cyl-1 status & $\begin{array}{l}\text { Retinal layer } \\
\text { thickness }(\mu \mathrm{M})\end{array}$ & inner & outer \\
\hline$+/+,+/-$ & $14.8 \pm 0.2$ & $7.1 \pm 0.8$ & $12.9 \pm 0.3$ \\
$-/-$ & $6.7 \pm 0.5$ & $3.8 \pm 0.2$ & $5.2 \pm 1.8$ \\
\hline
\end{tabular}

Observations were made on six eyes in each category. For individual eyes the retinal thickness and numbers of nuclei were measured at several points. Numbers refer to the mean values \pm S.D. no detectable cyclin Dl in MEFs from Cyl-1-1- mice, but these cells showed normal patterns of expression for cyclins D2 and D3. Although in wild-type cells, cyclin D1 accumulation precedes that of cyclin D2, in the Cyl$1^{-1-}$ MEF there was no compensatory appearance of cyclin D2 at an ealier time (Fig. 9). Similarly, there was no significant difference in the time of cyclin D3 accumulation. We also examined cyclin $\mathrm{A}$ and a presumed target of cyclin D1/cdk activity, pRb. In both nullizygous and wild-type cell lines, cyclin A levels became detectable at $15 \mathrm{hr}$, concomitant with the onset of DNA synthesis, and reached a maximum in mid- $G_{2} / M$. Similarly, $\mathrm{pRb}$ was detectable throughout the cell cycle, but its electrophoretic mobility became progressively retarded be-

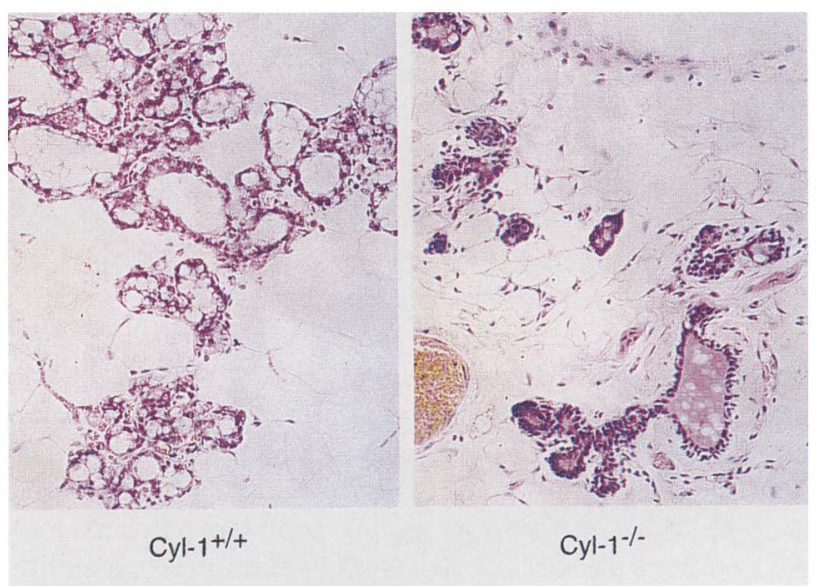

Figure 6. Histological examination of 2 day postpartum mammary gland from $\mathrm{Cyl} 11^{-1}-$ mice. Section through the mammary gland of a Cyl-1-/- mouse (right) shows poor acinar development and little evidence of lactational change with occasional vacuolated cells and little luminal secretion. In the normal gland (left) acinar proliferation, lactational activity of the epithelial cells, and luminal secretion are evident. 


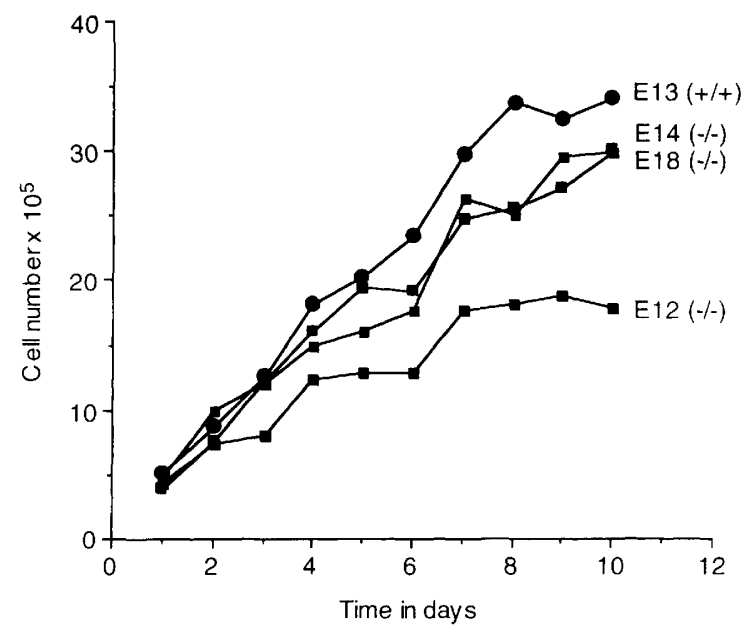

Figure 7. Growth curves for MEFs. (a) Cells from Cyl-1 $1^{-1-}$ embryos; $(0)$ cells from a Cyl-1 $1^{+/}$embryo.

tween 12 and $18 \mathrm{hr}$. This change in migration correlates with increasing degrees of phosphorylation /Buchkovich et al. 1989; De Caprio et al. 1989). In Cy1-1 ${ }^{-1-}$ MEF, the pattern of phosphorylation was comparable to wild-type cells.

\section{Discussion}

The results presented here show that a functional $\mathrm{Cyl}-1$ gene is not essential for the development of viable mice, although they are smaller than their $\mathrm{Cyl}-1^{+/-}$and $\mathrm{Cyl}$ $1^{+1+}$ littermates (Fig. 2), and there is a detectable level of embryonic lethality (Table 1 ). Cyl-1 ${ }^{-1-}$ mice reach sexual maturity and are able to produce live offspring, but they cannot rear their young because of an inability to produce milk. As a result, the mothers invariably kill their litters within 2 days of birth. The litters can be rescued by cross-fostering, suggesting that lactational inactivity is the main and possibly only reason why the natural mothers fail to nurture their young.

The cause of this failure to lactate has yet to be established. It could be that an absence of cyclin D1 severely curtails the normal proliferation and differentiation of the mammary gland that is associated with pregnancy. Alternatively, it may reflect an inadequate lactotropic response because of a deficiency of prolactin. Prolactin is secreted by the lactotropic cells of the anterior pituitary, and it is an intriguing possibility that pituitary insufficiency could also explain the small size of $\mathrm{Cyl}-1^{-1-}$ null mice. A proportional reduction in body size is a characteristic of pituitary dwarfism and is caused by inadequate levels of growth hormone. The latter is synthesized and stored in the somatotropic cells of the anterior pituitary. However, other anterior pituitary hormones such as follicle-stimulating hormone and luteinizing hormone appear to be secreted at sufficient levels to maintain fertility in most $C y 1-1^{-1-}$ mice. A detailed investigation of pituitary function will be necessary to determine whether there is a specific lack of growth hormone and prolactin-secreting cells in $\mathrm{Cyl}-1^{-1}$ mice.

Although the dwarfism and mammary gland defect may have a related cause originating in the pituitary, there is no obvious link between these defects and the retinal abnormality. All layers of the retina are present in the eyes of $\mathrm{Cyl}_{-1}^{-1-}$ mice, but there is a striking decrease in their thickness. Rather than affecting the differentiation of retinal cells, the absence of cyclin D1 appears to only affect their proliferation. Although transcripts for all three D-type cyclins are detectable in whole eyes (data not shown), this finding suggests that there is an inadequate compensatory mechanism for the loss of cyclin D1 in the retina. Whether this is attributable to a specific lack of cyclin D2 and/or D3 in this tissue remains to be determined.

As judged by the normal histological appearance of the majority of tissues in the Cyl-1-1- mice, most cells appear unaffected by the lack of cyclin D1. This contrasts

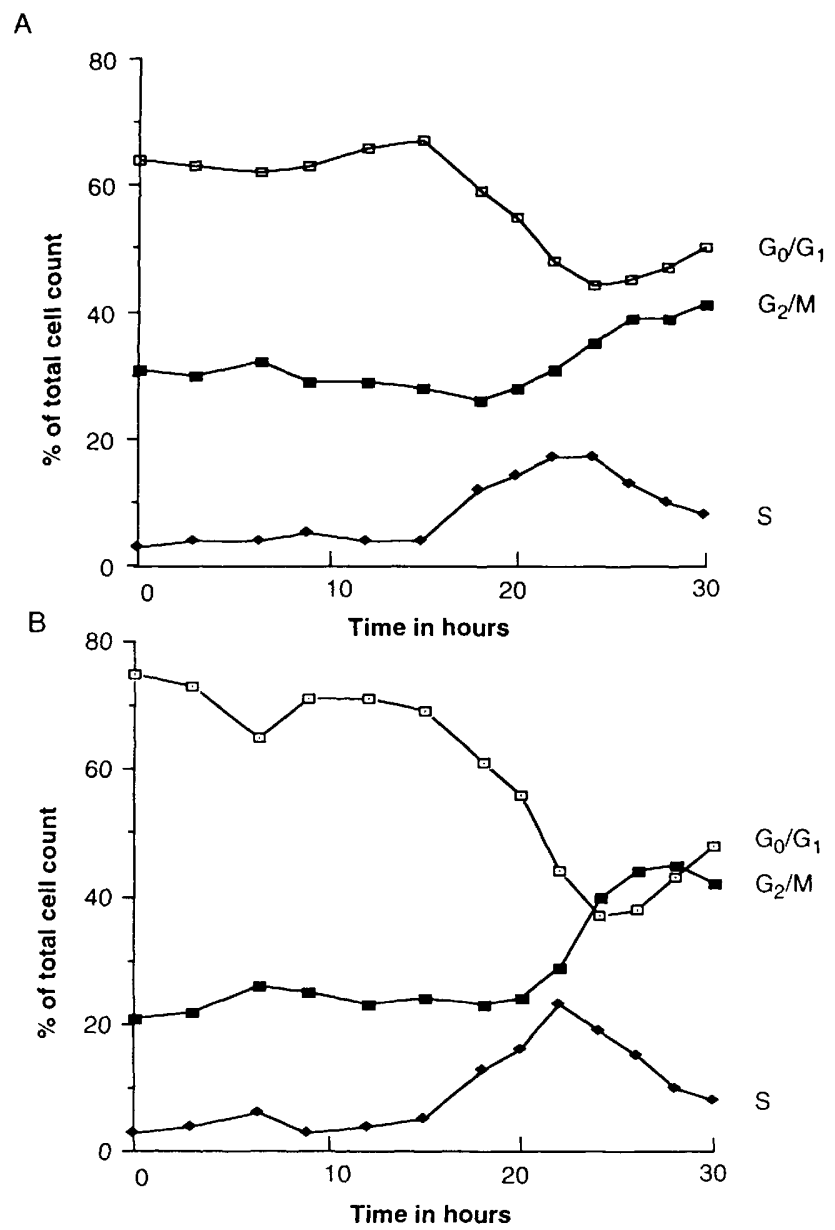

Figure 8. Cell cycle kinetics of MEFs. $(A)$ Cells derived from a wild-type mouse embryo (E8); $(B)$, cells from a nullizygous embryo (E6). After serum depletion for 3 days, the quiescent cells were stimulated by the addition of medium containing $10 \%$ FBS, and samples taken for FACS analysis at the indicated times. 

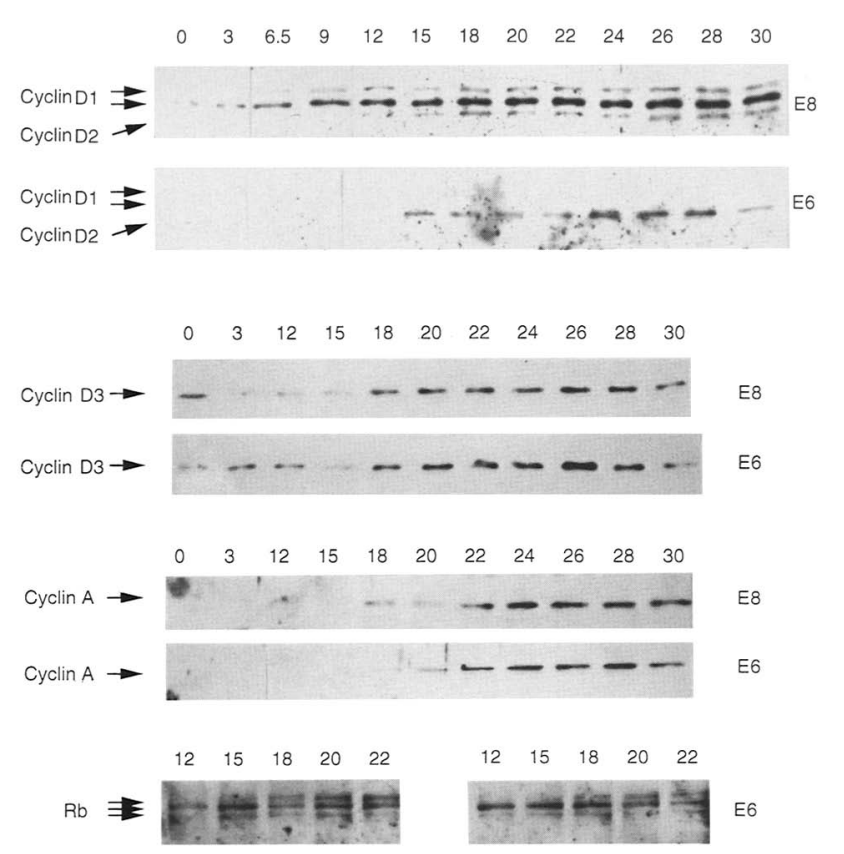

Figure 9. Expression of cell-cycle-dependent proteins. Immunoblot analyses at the indicated times of wild-type (E8) and nullizygous (E6) MEF extracts throughout the cell cycle (see Fig. 8). Approximate band sizes were as follows: cyclin $\mathrm{Dl}=$ doublet of $36 \mathrm{kD}$; cyclin $\mathrm{D} 2=34 \mathrm{kD}$; cyclin $\mathrm{D} 3=33 \mathrm{kD}$; cyclin $\mathrm{A}=56$ $\mathrm{kD}$; and $\mathrm{pRb} \sim 105-110 \mathrm{kD}$.

with the results reported for antibody microinjection and antisense experiments suggesting that abrogation of cyclin Dl function causes cells to arrest in $G_{1}$ (Baldin et al. 1993; Quelle et al. 1993; Lukas et al. 1994). It is possible that antibodies produce a more severe effect by interfering with proteins related to, and associated with, cyclin $\mathrm{D} 1$, such as cyclin D2, cdk4, and cdk6. Alternatively, there might be a major difference between the effects observed in tissue culture with those occuring in the whole animal. However, MEFs originating from the $\mathrm{Cyl}$ $1^{-1-}$ mice showed no significant differences in growth rates or in cell cycle kinetics, nor were we able to demonstrate a compensatory increase in the level or time of appearance of the two other D-type cyclins (Fig. 9). Moreover, within the limits of the analysis afforded by immunoblotting, the phosphorylation of $\mathrm{pRb}$ also appeared unaffected. However, because resolution of the cell division cycle is always compromised by imperfect cell synchrony, small differences in the length of $G_{1}$ or cyclin expression patterns might not be discernible. these preliminary studies were also conducted under optimal growth conditions, and it is possible that differences in the behavior of the nullizygous cells may only become apparent under more restrictive growth conditions when proliferation might be more dependent on signaling pathways that act preferentially through cyclin D1.

The observation that organs such as kidney, salivary gland, and seminal vesicles, which normally have readily detectable Cyl-1 transcript levels, are apparently unaffected in nullizygous mice indicates that during devel- opment, either cyclin D1 is not essential or there is some mechanism to compensate for its loss. This latter possibility suggests that either the D-type cyclins can substitute for one another or there are alternative signaling pathways. These alternative pathways may or may not involve the other D-type cyclins in the coupling of external signals with cell cycle control. However, in a few specialized tissues, such as the developing retina, there is an absolute requirement for cyclin D1. To distinguish between these possibilities it will be necessary to determine the normal pattern of $\mathrm{D}$-type cyclin expression in the affected tissues during embryogenesis and also to assess the concerted effect of combined deletions of D-type cyclins in mice.

\section{Materials and methods \\ Construction of targeting vector}

The Cyl-1 genomic locus was isolated as a recombinant bacteriophage $\lambda$ clone from a $129 / \mathrm{Sv}$ mouse genomic library using a mouse Cyl-1 cDNA probe (Smith et al. 1995). A 10-kb XbaI fragment was subcloned into Bluescript $\mathrm{KS}+$ plasmid (Stratagene) for further manipulation. The targeting vector was generated by inserting a PGK-neo cassette between the NcoI and NheI sites in the first exon of Cyl-1 by blunt end ligation (Adra et al. 1987). This was performed on a HindIII-ECoRI subclone and then reassembled into the equivalent of the $10-\mathrm{kb} X \mathrm{XaI}$ fragment (see Fig. 1).

\section{Electroporation and selection of ES cells}

GK129 ES cells derived from mouse strain 129/Ola were maintained on a monolayer of mitomycin C-inactivated, neomycinresistant, STO fibroblast feeder cells, as described previously (Robertson 1987). A suspension of trypsinized cells $\left[5 \times 10^{6} / \mathrm{ml}\right.$ in Dulbecco's modified Eagle medium (DMEM)| was electroporated with $20 \mu \mathrm{g}(1 \mathrm{mg} / \mathrm{ml})$ of linearized DNA using a Bio-Rad gene pulser $(190 \mathrm{~V}, 960 \mu \mathrm{F})$. Cells were plated immediately after transfection and allowed to recover for $24 \mathrm{hr}$ before selection in medium containing G418 $(300 \mu \mathrm{g} / \mathrm{ml})$. Cells were fed daily and after 9 days the resulting colonies were divided equally between two 96-well plates. When cells were confluent, one plate was frozen $\left(-80^{\circ} \mathrm{C}\right)$ while the duplicate was used to prepare DNA.

\section{Analysis of targeted ES cell clones}

The analysis of DNA from ES cell clones was initially carried out in 96-well plates according to the method of Ramirez-Solis et al. (1992). In brief, cells were washed with PBS, lysed in $50 \mu \mathrm{l}$ of $10 \mathrm{~mm}$ Tris- $\mathrm{HCl}(\mathrm{pH} 7.5)$ containing $10 \mathrm{~mm}$ EDTA, $10 \mathrm{~mm}$ $\mathrm{NaCl}, 0.5 \%$ sarcosyl, and $1 \mathrm{mg} / \mathrm{ml}$ of proteinase $\mathrm{K}$. After overnight incubation at $60^{\circ} \mathrm{C}, 100 \mu \mathrm{l}$ of a mix of $\mathrm{NaCl}$ and cold ethanol $(15 \mu \mathrm{l}$ of $5 \mathrm{M} \mathrm{NaCl} / \mathrm{ml})$ was added and DNA allowed to precipitate for $2 \mathrm{hr}$ (or overnight) at $4^{\circ} \mathrm{C}$. The supernatant was discarded and the DNA washed three times with $70 \%$ ethanol. Plates were left tilted to air-dry for 20 min before adding $35 \mu \mathrm{l}$ of restriction enzyme mixture $(1 \times$ restriction buffer, $100 \mu \mathrm{g} / \mathrm{ml}$ of BSA, $50 \mu \mathrm{g} / \mathrm{ml}$ of RNase, and 15 units of HindIII) to each sample. After thorough mixing, using a microtiter plate shaker, samples were incubated overnight at $37^{\circ} \mathrm{C}$. Electrophoresis and Southern blotting of the digested DNA was performed as described previously (Fantl et al. 1990). A 490-bp Sall-HindIII fragment (probe 1), which lies $3^{\prime}$ of the genomic sequences in the targeting vector, identified bands of $\sim 8.9$ and $10.5 \mathrm{~kb}$ corre- 
sponding to germ-line and homologous recombinant bands, respectively. Targeted clones were recovered from the duplicate plates and expanded in $35-\mathrm{mm}$ dishes. DNA from these colonies was analyzed further by KpnI digestion, which produced an endogenous fragment of $\sim 17 \mathrm{~kb}$ and a correspondingly larger $(+1.6 \mathrm{~kb})$ band from the mutant allele. These were identified using an 800-bp PstI-Pst I fragment (probe 2) located upstream of exon 1 .

\section{Generation of mice carrying the disrupted Cyl-1 allele}

Two different clones of targeted ES cells were used to generate chimeric mice according to procedures described previously (Bradley 1987). C57BL/6J blastocysts injected with 10-15 ES cells were transferred to pseudopregnant female mice. Chimeric mice, identifiable by agouti coat color, were mated with C57BL/ 6I mice. Offspring with agouti coat color were tested for the presence of the targeted locus by PCR. Heterozygotes were interbred, and PCR analysis was used to distinguish between offspring with no, one, or two copies of the mutant gene.

\section{Screening mice for the targeted gene by PCR}

DNA for PCR analysis was prepared from tissue obtained with an ear punch. Fresh tissue was incubated at $55^{\circ} \mathrm{C}$ in $40 \mu \mathrm{l}$ of buffer $150 \mathrm{~mm}$ at pH 8.0 containing $20 \mathrm{~mm} \mathrm{NaCl}, 0.1 \%$ SDS, and proteinase $\mathrm{K}$ at $1 \mathrm{mg} / \mathrm{ml}$ ) for $2 \mathrm{hr}$. Following addition of water (four volumes), samples were boiled for $5 \mathrm{~min}$, cooled on ice, and $2 \mu \mathrm{l}$ used for PCR. For the targeted allele, a 384 -bp product was generated using a sense oligonucleotide, 5'-GTAGCAGAGAGCTACAGACT-3' |nucleotide 17-36 in Cyl-1 (Smith et al. 1995|l, and antisense oligonucleotide, 5'-AGTGAGACGTGCTACTTCCA-3' |nucleotide $-264^{\prime}$ to $-288^{\prime}$ in the PGK promoter (Adra et al. 1987)|. To detect the wild-type allele, the PGK oligonucleotide was replaced with the antisense oligonucleotide, 5'-CATCCAGGTGGCCACGATTT-3' $\left(310^{\prime}-329^{\prime}\right)$, in Cyl-1 to give a product of $312 \mathrm{bp}$. As a positive control sense and antisense FGF3 oligonucleotides 5641-5660, and 6157'-6176', respectively (Moore et al. 1986), were used in all reactions giving rise to a product $535 \mathrm{bp}$.

\section{Northern blot analysis}

Total tissue RNA was prepared by solubilization in guanidine isothiocyanate and centrifugation through a cushion of cesium trifluoroacetate (Pharmacia). Samples $(20 \mu \mathrm{g})$ were fractionated by electrophoresis in formaldehyde-agarose gels. RNA was transferred to Hybond $\mathrm{N}$ (Amersham) and fixed by UV crosslinking. Hybridization $\left(60^{\circ} \mathrm{C}\right)$ and washing of filters $\left(65^{\circ} \mathrm{C}\right)$ was carried out as described previously (Smith et al. 1995).

\section{Cell lines and tissue culture}

MEF cultures were prepared from 13- to 14-day-old fetuses generated by mating mice heterozygous for the targeted Cyl-1 locus. Individual fetuses were dissected and cut into small pieces for digestion in isotonic trypsin $(0.25 \%)$. Released cells were removed and seeded onto $90-\mathrm{mm}$ culture dishes and grown in DMEM supplemented by $10 \%$ fetal bovine serum (FBS) for at least two passages before being used for cell cycle experiments. For time course studies, cells at $60 \%$ confluence were rendered quiescent by serum depletion (0.1\% FBS in DMEM) for 3 days. The cells were then refed with DMEM containing $10 \%$ FBS and processed for protein analysis or for flow cytometry at the indicated times.

Cell growth was measured by counting cells plated in dupli- cate dishes at intervals over a period of 10 days. The cells were refed every 2 days.

\section{Immunoblot analysis}

Synchronized subconfluent cells in $30-\mathrm{mm}$-diameter dishes were harvested at the indicated times in $400 \mu \mathrm{l}$ of Laemmli buffer, boiled for $2 \mathrm{~min}$ and sonicated for $5 \mathrm{sec}$. Proteins were electrophoresed through $10 \%$ or $12 \%$ polyacrylamide gels, transferred to Hybond/ECL/nitrocellulose or ImmobilonPVDF membranes for $1 \mathrm{hr}$ at $300 \mathrm{~mA}$. Protein loading was checked by Ponceau-S staining. Membranes were processed for antigen detection by enhanced chemiluminescence according to the manufacturer's, instructions (Amersham). Rabbit antisera were used to detect cyclin D1 and D2 (Bates et al. 1994), and cyclin A (gift of Tim Hunt, ICRF, London, UK), whereas monoclonal antibodies were used to detect cyclin D3 (Lukas et al. 1995) and retinoblastoma protein (Pharmingen). Anti-rabbit and anti-mouse horseradish peroxidase-conjugated secondary antibodies (Dakopat) were used appropriately.

\section{Flow cytometry}

For the analysis of cellular DNA content, 30-mm-diameter dishes of cells were harvested by trypsinization, washed once in $\mathrm{PBS}$, and fixed in $70 \% \mathrm{EtOH} / \mathrm{PBS}$. After multiple washes in PBS, the cells were resuspended in $100 \mu \mathrm{g} / \mathrm{ml}$ of RNase at $37^{\circ} \mathrm{C}$ for 15 min, washed in PBS, and stained with $50 \mu \mathrm{g} / \mathrm{ml}$ of propidium iodide. Fluorescence was measured above $600 \mathrm{~nm}$ on a BectonDickinson FACScan flow cytometer, and the number of cells plotted against DNA content.

\section{Histology}

For histological examination, dissected tissues fixed in $10 \%$ formal saline were processed and embedded in wax using routine procedures. Eyes were embedded in the vertical plane, and their maximun diameter measured by taking serial $4-\mu \mathrm{m}$ sections until the central region was reached. Retinal thickness from the ganglion cell layer to the choroid layer was also measured at several points. An ocular micrometer in an Olympus BH-2 microscope was used for all these measurements. Replicate counts for the number of cells in the inner and outer nuclear layers of each retina were made. Observations were restricted to the orientated central zone, avoiding the fovea and peripheral region where the cell layers are thinner.

\section{Radiology}

The jaw and skull of selected mice were analyzed in a Siemans Orbix maxillofacial X-ray unit at $52 \mathrm{kV}$ and $2 \mathrm{~mA}$.

\section{Acknowledgments}

We thank Tracy Crafton, Susan Northfield, Gill Hutchinson, and Julie Bee for their skill and patience in caring for the mice. We also thank Rona Buxton for help with the radiology, Gordon Peters and Mike Owen for comments and critical reading of the manuscript, and Jiri Bartek and Jiri Lukas for the monoclonal antibodies to cyclins D2 and D3.

The publication costs of this article were defrayed in part by payment of page charges. This article must therefore be hereby marked "advertisement" in accordance with 18 USC section 1734 solely to indicate this fact. 


\section{References}

Adra, C., P. Boer, and M. McBurney. 1987. Cloning and expression of the mouse pgk-1 gene and nucleotide sequence of its promoter. Gene 60: 65-74.

Ando, K., F. Ajchenbaumcymbalista, and J. Griffin. 1993. Regulation of $G_{1} / S$ transition by cyclin-D2 and cyclin-D3 in hematopoietic-cells. Proc. Natl. Acad. Sci. 90: 9571-9575.

Baldin, V., J. Lukas, M. Marcote, M. Pagano, and G. Draetta. 1993. Cyclin D1 is a nuclear-protein required for cell-cycle progression in $\mathrm{G}_{1}$. Genes \& Dev. 7: 812-821.

Bates, S., L. Bonetta, D. MacAllan, D. Parry, A. Holder, C. Dickson, and G. Peters. 1994. CDK5 (PLSTIRE) and CDK4 (PSKj3) are a distinct subset of the cyclin-dependent kinases that associate with cyclin D1. Oncogene 9: 71-79.

Beijersbergen, R., L. Carlee, R. Kerkhoven, and R. Bernards. 1995. Regulation of the retinoblastoma protein-related pl07 by $\mathrm{G}_{1}$ cyclin complexes. Genes \& Dev. 9: 1340-1353.

Bodrug, S.E., B.J. Warner, M.L. Bath, G.J. Lindeman, A.W. Harris, and J.M. Adams. 1994. Cyclin D1 transgene impedes lymphocyte maturation and collaborates in lymphomagenesis with the myc gene. EMBO J. 13: 2124-2130.

Buchkovich, K., L.A. Duffy, and E. Harlow. 1989. The retinoblastoma protein is phosphorylated during specific phases of the cell cycle. Cell 58: 1097-1105.

Bradley, A. 1987. Production and analysis of chimeric mice. In Teratocarcinomas and embryonic stem cells: A practical approach (ed. E.J. Robertson), pp. 113-151. IRL Press, Oxford, UK.

De Caprio, J.A., J.W. Ludlow, D. Lynch, Y. Furukawa, J. Griffin, H. Piwnica-Worms, C.-M. Huang, and D.M. Livingston. 1989. The product of the retinoblastoma susceptibility gene has propertics of a cell cycle regulatory element. Cell 58: $1085-1095$.

Dowdy, S.F., P.W. Hinds, K. Louie, S.I. Reed, A. Arnold, and R.A. Weinberg. 1993. Physical interaction of the retinoblastoma protein with human D cyclins. Cell 73: 499-511.

Ewen, M., H. Sluss, C. Sherr, H. Matsushime, J. Kato, and D. Livingston. 1993. Functional interactions of the retinoblastoma protein with mammalian D-type cyclins. Cell 73: 487497.

Fantl, V., M. Richards, R. Smith, G. Lammie, G. Johnstone, D. Allen, W. Gregory, G. Peters, C. Dickson, and D. Barnes. 1990. Gene amplification on chromosome band 1lq13 and oestrogen receptor status in breast cancer. Eur. /. Cancer 26: 423-429.

Hollingsworth, J. Jr., P.-L. Chen, and W.-H. Lee. 1993. Integration of cell cycle control with transcriptional regulation by retinoblastoma protein. Curr. Opin. Cell. Biol. 5: 194-206.

Hunter, T. and J. Pines. 1994. Cyclins and cancer II: Cyclin-D and CDK inhibitors come of age. Cell 79: 573-582.

Jiang, W., S. Kahn, P. Zhou, Y. Zhang, A. Cacace, A. Infante, S. Doi, R. Santella, and I. Weinstein. 1993. Overexpression of cyclin $\mathrm{dl}$ in rat fibroblasts causes abnormalities in growthcontrol, cell-cycle progression and gene-expression. Oncogene 8: 3447-3457.

Kato, J., H. Matsushime, S.W. Hiebert, M.E. Ewen, and C.J. Sherr. 1993. Direct binding of cyclin-D to the retinoblastoma gene-product (prb) and $\mathrm{pRb}$ phosphorylation by the cyclin D-dependent kinase cdk4. Genes \& Dev. 7: 331-342.

Lovec, H., A. Sewing, F. C. Lucibello, R. Muller, and T. Moroy. 1994. Oncogenic activity of cyclin Dl revealed through cooperation with Ha-ras-Link between cell-cycle control and malignant transformation. Oncogene 9: 323-326.

Lukas, J., M. Pagano, Z. Staskova, G. Draetta, and J. Bartek. 1994. Cyclin D1 protein oscillates and is essential for cell- cycle progression in human tumor-cell lines. Oncogene 9: 707-718.

Lukas, J., J. Bartkova, M. Welcker, O.W. Petersen, G. Peters, M. Strauss, and J. Bartek. 1995. Cyclin D2 is a moderately oscillating nucleoprotein required for $\mathrm{Gl}$ phase progression in specific cell types. Oncogene 10: 2125-2134.

Matsushime, H., M. Roussel, R. Ashmun, and C. Sherr. 1991. Colony-stimulating factor 1 regulates novel cyclins during the G1 phase of the cell cycle. Cell 65: 701-713.

Matsushime, H., M.E. Ewen, D.K. Strom, J.Y. Kato, S.K. Hanks, M.F. Roussel, and C.J. Sherr. 1992. Identification and properties of an atypical catalytic subunit $\left(\mathrm{p} 34^{\mathrm{PSK}-\mathrm{J} 3} / \mathrm{cdk} 4\right)$ for mammalian-D type-G1 cyclins. Cell 71: 323-334.

Matsushime, H., D.E. Quelle, S.A. Shurtleff, M. Shibuya, C.J. Sherr, and J.Y. Kato. 1994. D-type cyclin-dependent kinaseactivity in mammalian cells. Mol. Cell. Biol. 14: 2066-2076.

Meyerson, M. and E. Harlow 1994. Identification of $G_{1}$ kinaseactivity for cdk6, a novel cyclin D partner. Mol. Cell. Biol. 14: $2077-2086$.

Moore, R., G. Casey, S. Brookes, M. Dixon, G. Peters, and C. Dickson. 1986. Sequence, topography and protein coding potential of mouse int-2: A putative oncogene activated by mouse mammary tumour virus. EMBO I. 5: 919-924.

Norbury, C. and P. Nurse 1992. Animal cell cycles and their control. Annu. Rev. Biochem. 61: 441-470.

Pardee, A. 1989. Gl events and the regulation of cell proliferation. Science 246: 603-608.

Peters, G. 1994. The D-type cyclins and their role in tumorigenesis. I. Cell. Sci. S18: 89-96.

Pines, J. 1993a. Cyclin-dependent kinases-Clear as crystal. Curr. Biol. 3: 544-547.

1993b. Cyclins and cyclin-dependent kinases: take your partners. Trends Biochem. Sci. 18: 195-197.

Quelle, D., R. Ashmun, S. Shurtleff, I. Kato, D. Barsagi, M. Roussel, and C. Sherr. 1993. Overexpression of mouse D-type cyclins accelerates $G_{1}$ phase in rodent fibroblasts. Genes \& Dev. 7: 1559-1571.

Ramirez-Solis, R., J. Rivera-Perez, J. Wallace, M. Wimms, H. Zheng, and A. Bradley. 1992. Genomic DNA microextraction: A method to screen numerous samples. Anal. Biochem. 201: 331-335.

Reed, S. 1992. The role of p34 kinases in the G1 to S-phase transition. Annu. Rev. Cell. Biol. 8: 529-561.

Resnitzky, D., M. Gossen, H. Bujard, and S.I. Reed. 1994. Acceleration of the $G_{1} / S$ phase-transition by expression of $c y$ clin-D1 and cyclin-E with an inducible system. Mol. Cell. Biol. 14: 1669-1679.

Robertson, E.J. 1987. Embryo-derived stem cell lines. In Teratocarcinomas and embryonic stem cells: A practical approach (ed. E.J. Robertson), pp. 71-112. IRL Press, Oxford, UK.

Sherr, C.J. 1993. Mammalian $\mathrm{G}_{1}$-cyclins. Cell 73: 1059-1065.

Sherr, C. and J. Roberts 1995. Inhibitors of mammalian $\mathrm{G}_{1}$ cyclin-dependent kinases. Genes \& Dev. 9: 1149-1163.

Smith, R., G. Peters, and C. Dickson. 1995. Genomic organization of the mouse cyclin Dl gene (cyl-1). Genomics 25: 8592.

Wang, T.C., R.D. Cardiff, L. Zukerberg, E. Lees, A. Arnold, and E.V. Schmidt. 1994. Mammary hyperplasia and carcinoma in mmtv-cyclin Dl transgenic mice. Nature 369: 669-671.

Weinberg, R. 1995. The retinoblastoma protein and cell cycle. Cell 81: 323-330.

Xiong, Y., H. Zhang, and D. Beach. 1992. D-type cyclins associate with multiple protein-kinases and the DNA replication and repair factor pcna. Cell 71: 505-514. 


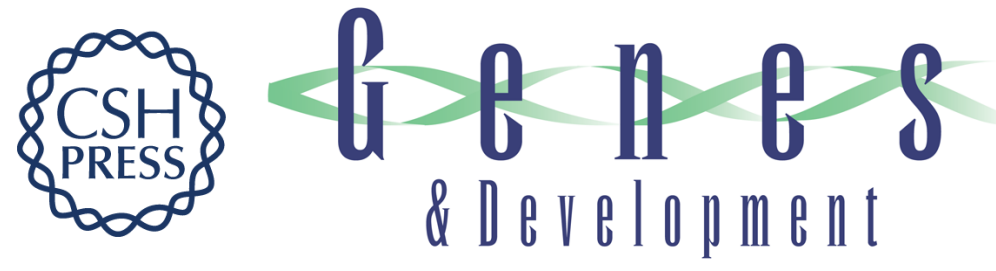

\section{Mice lacking cyclin D1 are small and show defects in eye and mammary gland development.}

V Fantl, G Stamp, A Andrews, et al.

Genes Dev. 1995, 9:

Access the most recent version at doi:10.1101/gad.9.19.2364

References This article cites 38 articles, 10 of which can be accessed free at:

http://genesdev.cshlp.org/content/9/19/2364.full.html\#ref-list-1

License

Email Alerting

Service

Receive free email alerts when new articles cite this article - sign up in the box at the top right corner of the article or click here.

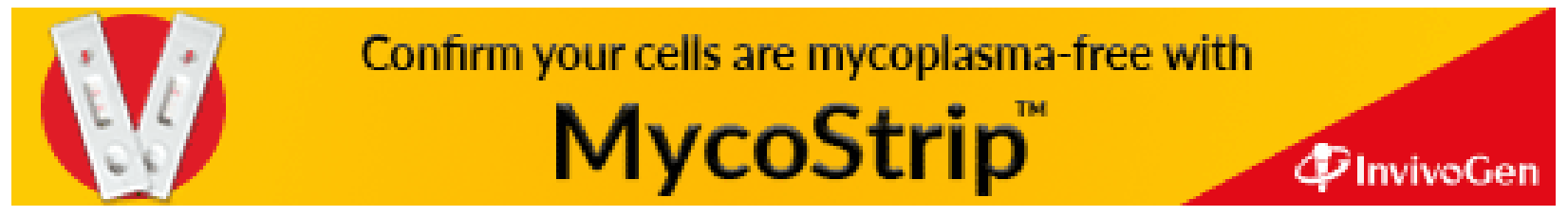

